\title{
A Case of Stage IV Non-Small Cell Lung Cancer Treated with Korean Medicine Therapy Alone
}

\author{
Dong-hyun Lee $^{a}$ Shin Seong ${ }^{a}$ Sung-su Kim ${ }^{a}$ Jae-bok Han ${ }^{a, b}$ \\ ${ }^{a}$ Soram Korean Medicine Hospital, and ${ }^{b}$ Department of East-West Medicine, \\ Graduate School, Kyung Hee University, Seoul, South Korea
}

\section{Key Words}

Cordyceps sinensis · Ginseng · Korean medicine · Non-small cell lung cancer · Pharmacopuncture $\cdot$ Trichosanthes kirilowii

\begin{abstract}
This report presents a case that shows a significant anticancer effect of Korean medicine therapy (KMT). A 79-year-old man, who was diagnosed as stage IV non-small cell lung cancer (NSCLC) in December 2012, was treated with KMT including intravenous pharmacopunctures and oral herbal medicine from February 22, 2013, until September 2013 without any surgical intervention, chemotherapy or radiotherapy. The intravenous pharmacopunctures were the wild ginseng pharmacopuncture, Cordyceps sinensis pharmacopuncture and Trichosanthes kirilowii pharmacopuncture. The oral herbal medicine used was soramdan, made of cultivated wild ginseng. The effectiveness of this therapy was evaluated with computed tomography and the Eastern Cooperative Oncology Group (ECOG) performance scale. The size of the tumor mass was markedly decreased and the ECOG performance scale was also improved. These results suggest that KMT alone can be an effective method to treat NSCLC.
\end{abstract}

(c) 2013 S. Karger AG, Basel

\section{Introduction}

Lung cancer is one of the most common cancers and the most common cause of cancer death [1]. Non-small cell lung cancer (NSCLC) (about 85\% of all lung cancers) has a poor prognosis as its 5-year survival rate is only about 16\% [2-4]. Major therapeutic modalities for lung cancer consist of surgery, chemotherapy and radiotherapy. If surgery is impossible, the 2-year survival rate is only $11 \%$, even after chemotherapy [5]. Chemotherapy can 
Lee et al.: A Case of Stage IV Non-Small Cell Lung Cancer Treated with Korean Medicine Therapy Alone

provoke various adverse reactions such as nausea, vomiting, anorexia, anemia, peripheral neuropathy and so forth. Some patients stop chemotherapy due to serious side effects, and others refuse to start chemotherapy for the fear of side effects. This case report is about an elderly patient with stage IV NSCLC who refused chemotherapy.

\section{Case Presentation}

A 79-year-old Korean man was admitted to hospital due to cough and dyspnea. He was diagnosed with cancer of the right, upper lobe through a computed tomogram (CT) scanning on December 11, 2012. After 1 week, he was diagnosed as NSCLC squamous cell carcinoma through a biopsy at a university hospital. Another week later, he was finally diagnosed as having stage IV NSCLC due to multiple metastatic nodules in the upper and lower lobes of the left lung, the right supraclavicular lymph nodes and the body of pancreas through a PETCT scan. Chemotherapy with cisplatin and gemcitabine was scheduled, but the patient refused it for a strong antagonistic feeling toward the expected side effects of chemotherapy and did not agree to any other therapy either. In his past medical history, he had been on medication for hypertension and diabetes for 10 years.

The patient was admitted to our hospital on February 22, 2013, with the chief complaint of cough and general weakness of the Eastern Cooperative Oncology Group (ECOG) scale 2. From February until September 2013, he has been on Korean medicine therapy (KMT) including pharmacopunctures and soramdan. The pharmacopunctures used were the wild ginseng pharmacopuncture (WGP), Cordyceps sinensis pharmacopuncture (CSP) and Trichosanthes kirilowii pharmacopuncture (TKP). Once a week, $10 \mathrm{ml}$ of each pharmacopuncture fluid was administered intravenously, and a pill of soramdan was administered orally twice a week.

The ECOG scale was checked every week. At first, general weakness was severe and the patient could not carry out any work activities. On average, he was in bed for $3 \mathrm{~h}$ a day to rest and for $8 \mathrm{~h}$ to sleep, so the ECOG score was 2. The score of 2 was maintained for 4 weeks after the beginning of treatment. From the fifth week on, he was recovering strength and could carry out light housework, so the ECOG score decreased to 1.

The size of the tumor (length of the longest axis) was measured with CT scanning and was $48 \mathrm{~mm}$ on the day of the first diagnosis (December 11, 2012). It increased to $54 \mathrm{~mm}$ by February 12, 2013, since he refused chemotherapy. However, by April 12, 2013, two months after he started KMT, the size of the tumor decreased to $17 \mathrm{~mm}$ and continued to decrease within the following 2 months to $11 \mathrm{~mm}$ on June 13, 2013. On August 12, 2013, the size of the tumor was stable (fig. 1).

\section{Discussion}

The major traditional KMT repertoire consists of acupuncture, moxibustion and herb decoction. One of the modern KMT practices is pharmacopuncture, which is a new form of therapy derived from a combination of herbal medicine and acupuncture. It is an injection of herbal extracts in the liquid state into affected areas or veins to induce a therapeutic response. Research on pharmacopuncture has been accomplished in China and Korea.

The pharmacopuncture fluid was produced through a distillation process. Briefly, $100 \mathrm{~g}$ of wild ginseng were decocted in distilled water for $2 \mathrm{~h}$, and the decoction was distilled to produce $1,000 \mathrm{ml}$ of WGP fluid, which, in turn, was filtered with $0.45-$ and $0.2-\mu \mathrm{m}$ filters and 


\begin{tabular}{l|l}
\hline DOI: $10.1159 / 000356061$ & $\begin{array}{l}\text { C 2013 S. Karger AG, Basel } \\
\text { www.karger.com/cro }\end{array}$ \\
\hline
\end{tabular}

Lee et al:: A Case of Stage IV Non-Small Cell Lung Cancer Treated with Korean Medicine Therapy Alone

sterilized in vials. CSP and TKP were also produced through a similar distillation process. To yield 2,000 ml of CSP fluid, $150 \mathrm{~g}$ of $C$. sinensis were used, and to yield 2,000 ml of TKP fluid, $300 \mathrm{~g}$ of the root of $\mathrm{T}$. kirilowii were necessary. The filtering and sterilization process was the same as the one for WGP. Soramdan was made of wild ginseng. Briefly, $500 \mathrm{~g}$ of wild ginseng were ground and mixed with $500 \mathrm{~g}$ of honey, divided into 4-g pills and wrapped with gold foils.

There has been various research on the anticancer effect of wild ginseng. Through the oral intake of wild ginseng, various ginsenosides can be absorbed to the blood stream. Ginsenoside Rg1 showed a clinical effect in advanced gastric cancer patients [6]. In some cases, WGP maintained NSCLC and advanced gastric cancer stable for more than 1 year, with a good quality of life [7]. An inoperable Klatskin tumor patient survived for more than 4.5 years with the combination of palliative care and KMT including WGP [8].

C. sinensis has been reported to have pro-apoptotic effects on human lung adenocarcinoma A549 cells [9], to prolong the survival of hepatocellular cancer patients [10] and to act as an adjuvant in cancer therapy [11].

T. kirilowii has been reported to have an antitumor effect through experiments using HeLa cells, B16-F10 melanoma cells and A549 lung cancer cells [12-14].

Thus, WGP, CSP, TKP and soramdan are assumed to be effective in the treatment of lung cancer and therefore used in this case. As a result, the ECOG scale was improved from 2 to 1 , and the size of the tumor, which increased from 48 to $54 \mathrm{~mm}$ in the 2 months without any treatment, finally decreased from 54 to $11 \mathrm{~mm}$ within 6 months of KMT and remained stable afterwards.

Most reported cases in which cancer was improved were accompanied by surgery, chemotherapy or radiotherapy. It is significant that the current case showed improvement only with KMT and without any other treatment such as chemotherapy and radiotherapy. It is difficult to draw a conclusion on the therapeutic effect of KMT on NSCLC from this single case; however, it surely argues for a more active use of pharmacopunctures and soramdan in the treatment of NSCLC. Furthermore, additional case reports and clinical research are needed to prove the effectiveness of KMT.

\section{References}

1 Jemal A, Siegel R, Xu J, Ward E: Cancer statistics, 2010. CA Cancer J Clin 2010;60:277-300.

-2 Asamura H, Goya T, Koshiishi Y, Sohara Y, Tsuchiya R, Miyaoka E: How should the TNM staging system for lung cancer be revised? A simulation based on the Japanese Lung Cancer Registry populations. J Thorac Cardiovasc Surg 2006;132:316-319.

3 Hayat MJ, Howlader N, Reichman ME, Edwards BK: Cancer statistics, trends, and multiple primary cancer analyses from the Surveillance, Epidemiology, and End Results (SEER) Program. Oncologist 2007;12:20-37.

-4 Herbst RS, Heymach JV, Lippman SM: Lung cancer. N Engl J Med 2008;359:1367-1380.

5 Schiller JH, Harrington D, Belani CP, Langer C, Sandler A, Krook J, Zhu J, Johnson DH: Comparison of four chemotherapy regimens for advanced non-small-cell lung cancer. N Engl J Med 2002;346:92-98.

6 Arichi S, Hayashi T: Antitumor agent containing specific saponins. German patent offen 1980;40:828-851.

$\rightarrow 7$ Lee JH, Kwon KR, Cho CK, Han SS, Yoo HS: Advanced cancer cases treated with cultivated wild ginseng pharmacopuncture. J Acupunct Meridian Stud 2010;3:119-124.

-8 Han JB, Im CR, Lee JW, Kim SS, Seong S: A case of inoperable klatskin tumor showing response to wild ginseng pharmacopuncture. Orient Pharm Exp Med 2013;13:235-237.

-9 Thakur A, Hui R, Hongyan Z, Tian Y, Tianjun C, Mingwei C: Pro-apoptotic effects of Paecilomyces hepiali, a Cordyceps sinensis extract on human lung adenocarcinoma A549 cells in vitro. J Cancer Res Ther 2011;7:421-426.

10 Yukie N, Hiroshi M, Masato M, Junichi S, Keiichi H, Hajime S: Evidence that naturopathic therapy including Cordyceps sinensis prolongs survival of patients with hepatocellular carcinoma. Integr Cancer Ther 2013;12:50-68. 


\begin{tabular}{l|l}
\hline DOI: $10.1159 / 000356061$ & $\begin{array}{l}\text { C } 2013 \text { S. Karger AG, Basel } \\
\text { www.karger.com/cro }\end{array}$ \\
\hline
\end{tabular}

Lee et al.: A Case of Stage IV Non-Small Cell Lung Cancer Treated with Korean Medicine Therapy Alone

11 Zhu JS, Halpern GM, Jones K: The scientific rediscovery of a precious ancient Chinese herbal regimen: Cordyceps sinensis: part II. J Altern Complement Med 1998;4:429-457.

12 Dou CM, Li JC: Effects of extracts of trichosanthes root tubers on HepA-H cells and HeLa cells. World J Gastroenterol 2004;10:2091-2094.

-13 Oh H, Mun YJ, Im SJ, Lee SY, Song HJ, Lee HS, Woo WH: Cucurbitacins from Trichosanthes Kirilowii as the inhibitory components on tyrosinase activity and melanin synthesis of B16/F10 melanoma cells. Planta Med 2002;68:832-833.

14 Li CT, Lin CH, Kao TY, Wu MF, Yeh CS, Yeh KT, Ko JL: The mechanisms of action of Tianhua( ${ }^{\mathrm{TM}}$ ) on antitumor activity in lung cancer cells. Pharm Biol 2010;48:1302-1309. 


\section{Case Reports in Oncology}

\begin{tabular}{l|l}
\hline \multicolumn{2}{l}{ Case Rep Oncol 2013;6:574-578 } \\
\hline DOI: 10.1159/000356061 & $\begin{array}{l}\text { (c) 2013 S. Karger AG, Basel } \\
\text { www.karger.com/cro }\end{array}$ \\
\hline
\end{tabular}

Lee et al.: A Case of Stage IV Non-Small Cell Lung Cancer Treated with Korean Medicine Therapy Alone

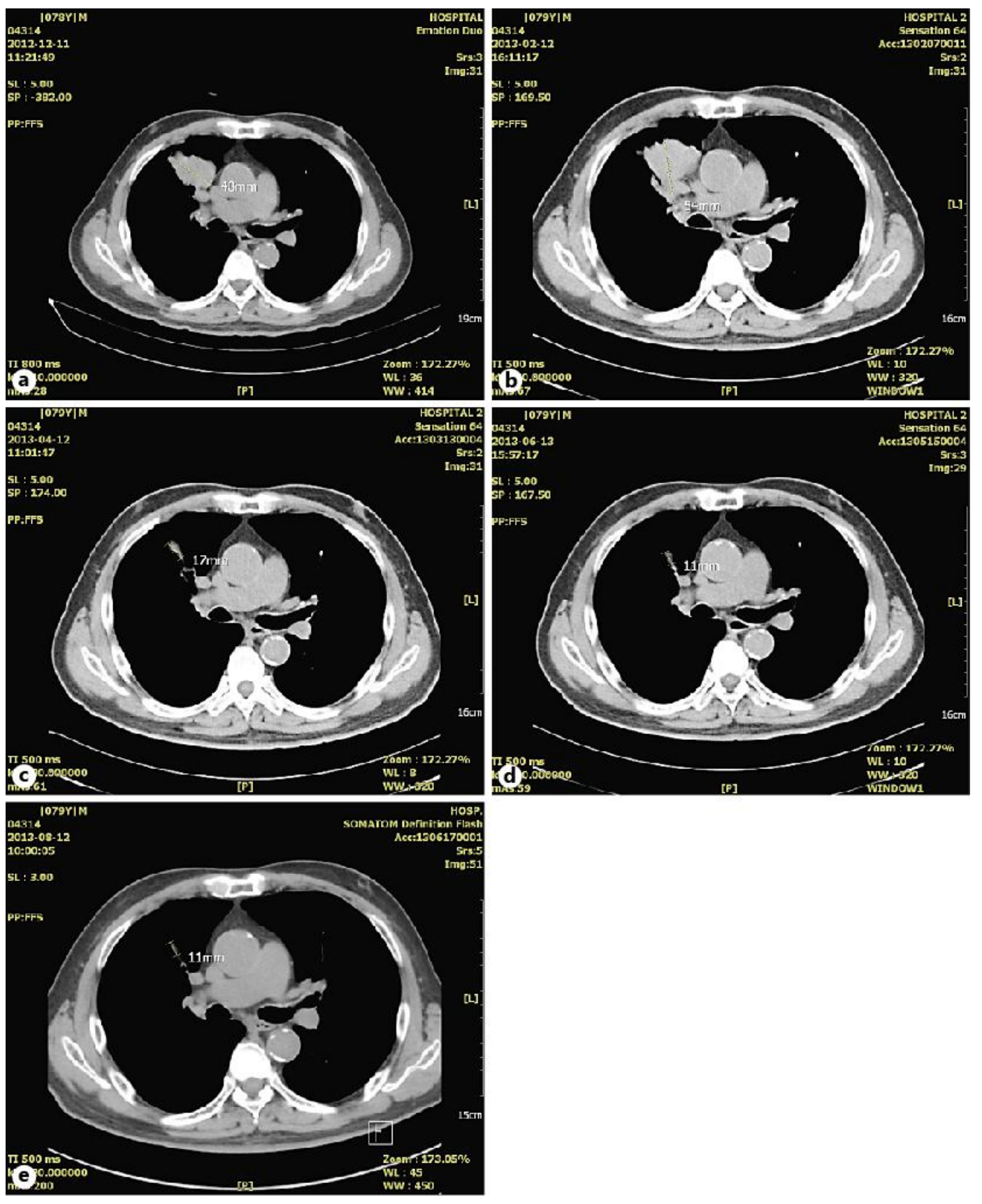

Fig. 1. CT images. a An image of December 11, 2012: the longest axis of the mass (LAM) in the right upper lobe is $48 \mathrm{~mm}$. b An image of February 12, 2013: LAM increased to $54 \mathrm{~mm}$ without any treatment for 2 months. c An image of April 12, 2013: LAM decreased to $17 \mathrm{~mm}$ with a 2-month KMT consisting of pharmacopunctures and soramdan. $\mathbf{d}$ An image of June 13, 2013: LAM decreased to $11 \mathrm{~mm}$ with KMT for 2 more months. e An image of August 12, 2013: LAM is stable after another 2-month KMT. 